\title{
A Sister Recalls Joyce in Dublin*
}

\author{
MAY JOYGE MONAGHAN
}

'Jim, as we used to call him,' said Mrs Monaghan, 'was very gentle and quiet. I don't ever remember him going out with my father drinking. He didn't drink much.' Mrs Monaghan's father, John Stanislaus Joyce, is a leading character in his son's writings, and he is still remembered in Dublin as a drinker in the epic Irish tradition.

'My mother was very religious,' said Mrs Monaghan. 'My father was the opposite, anything but. He was a man about town. "I get more out of life than any white man" - so he used to say. He had a beautiful voice. So had Jim. My mother was a very good pianist. There always seemed to be music and playing and singing in spite of difficulties financially.

'My father amused Jim - with his wit and his vitality. My father was full of everything, whistling around, always wanting to live it up. You'd think he hadn't a care in the world. And ten of us there to be provided for. My mother was always trying to keep the men's souls right, trying to get them to go to mass and confession.

'Did Jim and his father ever fight? Jim wasn't a fighter, you know. His father would upbraid him for being out late: "Where were you last night? What hour did you get in?" "I was out with the poet" - Jim made that answer once. I think it could have been Padraic Colum.'

\section{NOTE}

Joyce's sister, Mrs May (Mary Kathleen) Joyce Monaghan (1890-1966), was in New York at the invitation of Mrs Frances Steloff, owner of the Gotham Book Mart and President of the James Joyce Society, to help celebrate the 82nd anniversary of Joyce's birth. She gave this interview at the Gotham Book Mart.

* Extracted from an interview in the New York Times, 3 February 1964, p. 25. Interviewed by Brian O'Doherty. 